\title{
MENINJAU KEMBALI GLASGOW COMA SCALE: MASIHKAH RELEVAN?
}

\author{
REVISITING THE GLASGOW COMA SCALE: IS IT STILL RELEVANT?
}

Arthur Hendrik Philips Mawuntu*

\begin{abstract}
Glasgow Coma Scale (GCS) is the most popular quantitative assesment of consciousness. Its popularity is gained by the simplicity of the assessment making the scale easy to be performed by medical officers from various background. Glasgow Coma Scale was rapidly adopted worldwide since its first publication in 1974. The wide adoption of the scale has affected the improvement of head injury management as well as other neurological conditions. Furthermore, many large scale studies about head injury have used this scale to evaluate degree of severity and prognosis. After more than 40 years, GCS has underwent various critisms and modifications. The last modification was published on 2014. Some cutting edge devices and new evaluation methods have been introduced in the last two decades that, probably, reduced the role of GCS. However, GCS still seems to be relevant in evaluating patients'clinical condition periodically, therefore we need to understand the development of GCS, its relevance in the present, and some modification of GCS.
\end{abstract}

Keywords: Glasgow Coma Scale, history, relevance

\section{ABSTRAK}

Glasgow Coma Scale (GCS) atau Skala Koma Glasgow (SKG) adalah metode penilaian kuantitatif kesadaran yang paling popular. Popularitasnya justru disebabkan oleh kesederhanaan metode penilaiannya, sehingga mudah dikerjakan oleh petugas kesehatan dari berbagai latar belakang. Glasgow Coma Scale diadopsi dengan cepat di seluruh dunia setelah dipublikasikan pertama kali pada tahun 1974. Hal ini berdampak secara luas pada perbaikan manajemen cedera kepala dan penyakit neurologis lain, serta berbagai penelitian. Setelah lebih dari 40 tahun, skala ini melewati berbagai kritik dan modifikasi, yaitu terakhir pada tahun 2014. Berbagai alat pemeriksaan canggih dan metode penilaian baru telah diperkenalkan dalam dua dekade terakhir sehingga mungkin mengurangi peran GCS. Meskipun demikian, masih digunakan untuk mengevaluasi keadaan klinis pasien secara berkala, sehingga perlu diketahui tentang perjalanan GCS, relevansinya di masa kini, serta beberapa modifikasi SKG.

Kata kunci: Relevansi, sejarah, Skala Koma Glasgow

*Bagian/KSM Neurologi FK Universitas Sam Ratulangi/RSUP Prof. Dr. R.D. Kandou, Manado. Korespondensi: arthurmawuntu@, unsrat.ac.id.

\section{PENDAHULUAN}

Evaluasi tingkat kesadaran dan perubahannya merupakan salah satu hal penting dalam penatalaksanaan cedera kepala traumatik maupun kerusakan otak lainnya. Suatu skala penilaian kesadaran idealnya harus handal, sahih, mudah digunakan, mudah diingat, dan mampu memprediksi luaran pasien. Skala yang terlalu rumit akan cepat ditinggalkan karena sulit dikerjakan atau menyita waktu. Sebaliknya, skala yang terlalu sederhana tidak akan mampu mendeteksi perubahan tingkat kesadaran yang penting dengan akurat. ${ }^{1}$

Glasgow Coma Scale (GCS) atau Skala Koma Glasgow (SKG) merupakan metode penilaian kuantitatif kesadaran yang paling populer, meskipun masih memiliki beberapa kekurangan. ${ }^{2}$ Saat ini muncul berbagai skala pemeriksaan kesadaran alternatif maupun modalitas pemeriksaan penunjang yang canggih, sehingga perlu diketahui sejarah GCS dan relevansinya saat ini. ${ }^{1,3}$

\section{PEMBAHASAN}

\section{Perjalanan GCS di Masa Lalu}

Penilaian kesadaran sebelum GCS dilakukan dengan sangat bervariasi. Hal ini menyebabkan kebingungan dalam evaluasi pasien, baik saat menilai perubahan pasien dari waktu ke waktu, atau saat mengomunikasikan keadaan pasien dengan petugas kesehatan lain. ${ }^{4}$ Salah satu metode pencatatan status neurologi paling awal adalah metode pencatatan oleh Ommaya sekitar tahun 1966 dari National Institute of Neurological Diseases and Blindness Bethesda, Maryland, Amerika Serikat. Ahli bedah saraf ini mencatat perkembangan harian pasien yang meliputi tingkat kesadaran, aktivitas motorik dan perilaku, pupil, refleks kornea, tekanan darah, denyut nadi, 
pernapasan, dan suhu badan dalam suatu kartu yang disebut Kartu Tanda Vital (Vital Signs Chart). Metode ini dikenal dengan Skala Koma Ommaya (Ommaya Coma Scale), ${ }^{1}$ namun tidak ada informasi penggunaannya di luar institusi tersebut.

Glasgow Coma Scale pertama kali diperkenalkan pada tahun 1974 oleh Graham Teasdale dan Bryan Jennett, dua orang ahli bedah saraf dari Glasgow, Skotlandia. Mereka memublikasikan suatu metode penilaian kesadaran baru yang sederhana di jurnal Lancet, yang kemudian dikenal sebagai Glasgow Coma Scale. ${ }^{5}$

Glasgow Coma Scale digunakan untuk mengevaluasi respons pasien terhadap 3 aspek, yaitu membuka mata (eye opening/E), respons motorik (motor response/M), dan respons verbal (verbal response/V). Komponen E diberi nilai 1-4, $M$ bernilai 1-6, dan skor V antara 1-5. Nilai GCS adalah penjumlahan skor masing-masing komponen, sehingga nilai minimalnya tiga (bukan nol) dan maksimal 15. ${ }^{2}$ Hal ini menjadi suatu terobosan besar dalam evaluasi kesadaran yang sebelumnya bermacam-macam dan bersifat semi kuantitatif menjadi kuantitatif dengan reliabilitas yang baik. ${ }^{1,4-5}$

Singkatan GCS sendiri sering disebut memiliki dua makna yaitu Glasgow Coma Scale dan Glasgow Coma Score. Istilah scale (skala) mewakili penilaian untuk masing-masing komponen, sedangkan skor (score) mengacu pada total penjumlahan ketiga komponen. Selanjutnya praktik menggunakan skor kumulatif (penjumlahan ketiga komponen GCS) diadopsi oleh dokter-dokter lain. Namun untuk evaluasi klinis berkala, Teasdale tetap menganjurkan agar GCS dinilai dan dicatat perkomponen, bukan hanya melihat skor akhirnya. ${ }^{5-6}$

Sebelum dilakukan kuantifikasi hingga menjadi skor, GCS awalnya merupakan sistem penilaian tanpa angka. Selanjutnya derajat masingmasing komponen penilaian dikonversi ke dalam angka. Angka terendah tidak memakai nilai 0, melainkan $1 .{ }^{1}$

Setelah diberikan angka, para klinisi membuat skor total dari masing-masing komponen. Padahal, GCS sebenarnya tidak dimaksudkan untuk dinilai seperti itu. Namun demikian, hal ini sulit dihindari karena lebih memudahkan dalam membuat instruksi, seperti "Apabila GCS 8, intubasi". Batasan derajat cedera kepala ringan-sedang-berat juga mengacu pada skor kumulatif GCS tertentu. ${ }^{7-8}$ Selain itu, banyak penelitian cedera kepala menggunakan nilai skor kumulatif GCS dalam analisis statistiknya., 1,49-10

Pertanyaan menarik adalah alasan penilaian komponen membuka mata, respons motorik, dan respons verbal. Menurut Teasdale dan Jennett, membuka mata spontan dengan siklus tidur/bangun merupakan indikasi bahwa mekanisme aktivasi kesadaran di batang otak aktif. Respons motorik yang dibangkitkan di anggota gerak dengan berbagai macam pola gerak yang timbul dapat menjadi petunjuk fungsi susunan saraf pusat. Adapun respons verbal diperiksa karena tanda awal yang umum dilihat pada pulihnya kesadaran adalah pasien mampu mengeluarkan kata-kata yang dapat dimengerti. ${ }^{1,4}$

Teasdale dan Jennet mengeksklusi pemeriksaan refleks batang otak dari skala ini, karena sulit dikerjakan dan diinterpretasikan oleh dokter dan perawat junior. Selain itu, mereka menghindari pemeriksaan GCS menjadi terlalu lama atau terlalu mengganggu pasien, karena penilaiannya dimaksudkan untuk dikerjakan secara berkala. ${ }^{4}$

Pernah ada anekdot yang mengatakan GCS dibuat di suatu pub di Glasgow. Tentu hal tersebut tidak benar. Pengembangan GCS dimulai sejak tahun 1971 di Unit Bedah Saraf Institute of Neurological Sciences, Glasgow, Kerajaan Inggris. Di institut tersebut, penelitian GCS tidak terbatas dilakukan pada pasien trauma saja tetapi pada pasien dengan gangguan otak akut lain seperti stroke, termasuk perdarahan subaraknoid. Tujuan penelitian tersebut adalah untuk membuat suatu metode penilaian kesadaran yang jelas dan konsisten. Selain itu, penelitian ini juga bertujuan mencari hubungan antara tingkat kesadaran pasien saat masuk rumah sakit dengan luaran pasien tersebut. Implementasi GCS diujikan kepada para dokter muda dan perawat. Beberapa ahli bedah saraf dan neurolog seperti Fred Plum dari Cornell University, New York, dan David Shaw dari University of Newcastle, Inggris, diminta menelaah metode ini. ${ }^{4}$ 
Komponen respons motorik GCS awalnya memiliki skor total 5 sehingga skor kumulatif GCS menjadi 14. Komponen fleksi tidak dibedakan menjadi fleksi normal dan fleksi abnormal, karena sukar dibedakan oleh pemeriksa yang belum berpengalaman. Namun ternyata pembedaan tersebut memiliki nilai prognostik. Akhirnya pada tahun 1979 komponen fleksi dibedakan menjadi fleksi normal dan fleksi abnormal, sehingga skor total komponen motorik menjadi 6 dan skor kumulatif GCS menjadi $15 .{ }^{1}$

Evaluasi GCS kemudian diaplikasikan pada pasien anak. Secara umum, evaluasi GCS pada anak berusia di atas lima tahun dapat dilakukan tanpa modifikasi. Pada usia lima tahun ke bawah, respons verbal dan respons motorik perlu dimodifikasi. Terdapat beberapa cara penilaian kesadaran pada anak tetapi belum ada yang diterima secara umum.

Salah satu tonggak penting diseminasi GCS ke seluruh dunia adalah saat GCS dimasukkan dalam edisi pertama buku manual Advanced Trauma Life Support (ATLS) pada tahun 1980. Cepatnya adopsi ATLS di seluruh dunia juga mempercepat diseminasi GCS. Hal ini diikuti oleh kursus-kursus life support yang lain seperti Basic Life Support (BLS), General Emergency Life Support (GELS), dan Advanced Neurology Life Support (ANLS). Sampai tahun 2018, GCS masih terus digunakan dalam buku manual ATLS dan beberapa buku manual pelatihan kegawatdaruratan lain. ${ }^{11-12}$

Pada tahun 1988, GCS digunakan oleh World Federation of Neurosurgical Societies (WFNS) untuk mengklasifikasikan derajat keparahan pasien perdarahan subaraknoid. Beberapa sistem klasifikasi penyakit lain ikut menggunakan GCS, seperti cedera kepala dan meningitis tuberkulosis. Glasgow Coma Scale juga menjadi salah satu komponen dalam kriteria masuk ruang perawatan kritis/intensif ataupun intubasi. Saat ini International Classification of Disease (ICD) edisi ke-11 telah memasukkan GCS dalam bab Cedera dan Neurologi. ${ }^{4}$

Namun tingginya tingkat adopsi GCS di dunia mengakibatkan timbulnya kritik. Kritik pertama adalah masalah bias. Pada saat menilai komponen respons verbal, maka adanya afasia, demensia, gangguan tumbuh kembang, atau trakeostomi akan membatasi penilaian. Demikian pula terdapat bias pada penilaian komponen membuka mata (adanya trauma mata dan edema periorbita berat) dan respons motorik (cedera spinal dan cedera anggota gerak). ${ }^{13}$

Komponen respons verbal merupakan komponen yang sering sukar dinilai pada pasien dengan afasia, terintubasi atau menjalani trakeostomi. Upaya menggunakan kode pada komponen V menyulitkan penilaian skor total dan penentuan prognosis. Beberapa klinisi menggunakan metode skor verbal prediktif dengan melihat nilai dari dua komponen lain yang dapat diperiksa. Ada juga yang mengambil nilai rata-rata komponen $\mathrm{E}$ dan $\mathrm{M}$ lalu menambahkannya ke komponen $\mathrm{V}$ (pseudoscoring). Untuk tujuan penelitian, beberapa peneliti akhirnya hanya mencatat komponen M saja. Namun demikian, hal ini tidak memberikan hasil yang akurat., ${ }^{13-15}$

Selain masalah bias, pemeriksaan GCS juga sering dilakukan dengan mengira-ngira karena pemeriksa merasa pemeriksaan GCS yang benar tidak praktis. Dalam suatu penelitian untuk mengetahui pengetahuan klinisi tentang GCS, ditemukan hampir setengah neurolog dan residen neurologi tidak mampu menyebutkan komponen respons verbal secara akurat. ${ }^{16}$ Reliabilitas GCS juga berkurang saat digunakan skor kumulatif, padahal skor kumulatif sering digunakan untuk berbagai tujuan klinis atau penelitian. ${ }^{17}$ Hubungan antara penurunan GCS dengan mortalitas pasien noncedera kepala juga tidak bisa diasumsikan sama dengan pasien cedera kepala, meskipun banyak sistem penilaian klinis pasien noncedera kepala menggunakan GCS dalam komponen penilaiannya. ${ }^{18}$

\section{Hal-hal yang Tetap dan Berubah Saat Ini}

Pada tahun 2014, Teasdale dkk mengeluarkan suatu pembaruan terakhir dalam pemeriksaan GCS (Tabel 1). ${ }^{4,19}$ Skor GCS masih tetap digunakan namun terdapat perubahan pada urutan pemeriksaan, beberapa istilah dalam kriteria dan tingkatan, serta cara memberikan stimulus (Gambar 1).

\section{Teknik Pemeriksaan}

Saat ini, dianjurkan untuk melakukan evaluasi GCS menggunakan suatu urutan tertentu seperti yang diperlihatkan dalam Gambar 2. ${ }^{19-20}$ 


\section{Membuka Mata (Eye Opening)}

Suara pemeriksa harus cukup lantang saat meminta pasien membuka mata. Jika pasien membuka mata saat diperintahkan, sambil memberikan perintah yang lain, perhatikan pasien dapat mempertahankan matanya terbuka atau hanya sebentar lalu dipejamkan lagi. Pasien yang tetap membuka mata saat diberikan perintah yang lain mendapatkan skor tertinggi (4) untuk komponen membuka mata. ${ }^{20}$

Hal lain yang perlu ditegaskan adalah lokasi stimulus tekan. Lokasi stimulus tekan untuk pemeriksaan komponen membuka mata adalah di bantalan kuku

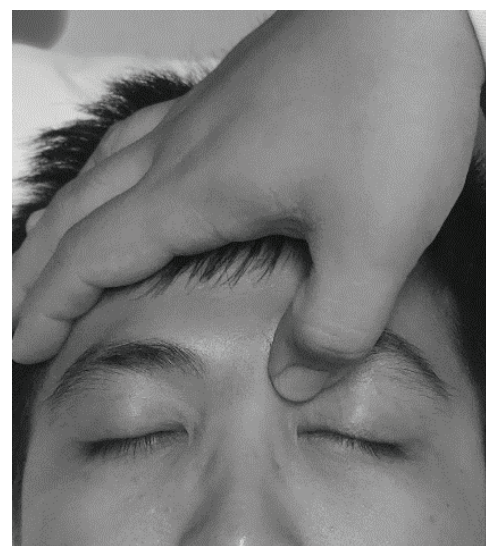

$\mathbf{A}$

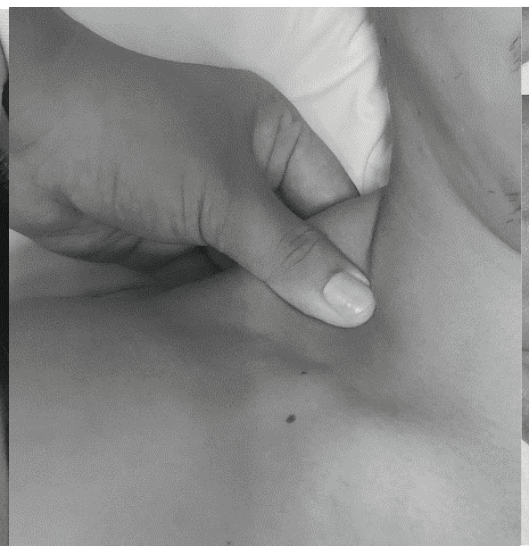

B

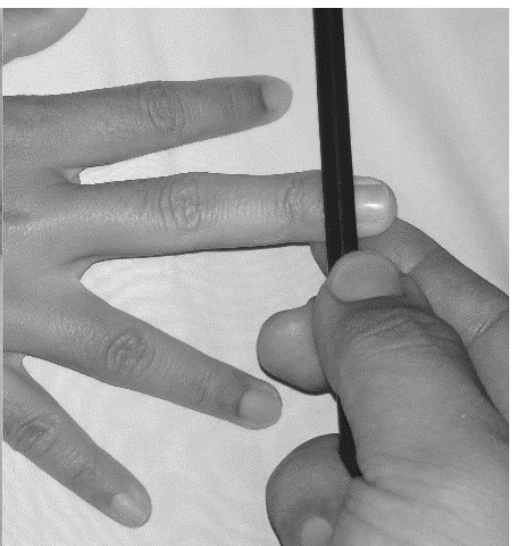

C

Gambar 1. Lokasi untuk Stimulasi Secara Fisik

A: Tekanan pada takik supraorbita; B: Cubitan pada trapezius; C: Tekanan pada jari.

Tabel 1. Skala Penilaian GCS Terbaru ${ }^{20}$

\begin{tabular}{|c|c|c|}
\hline Kriteria & Tingkatan & Skor \\
\hline \multicolumn{3}{|l|}{ Membuka mata/eye opening (E) } \\
\hline Membuka sebelum diberi stimulus & Spontan & 4 \\
\hline Membuka setelah diberi perintah suara/suara lantang & Terhadap suara & 3 \\
\hline Membuka setelah diberi stimulus pada ujung jari & Terhadap tekanan & 2 \\
\hline Tidak membuka sama sekali (tanpa faktor yang menghalangi) & Tidak ada & 1 \\
\hline Tertutup karena faktor lokal & Tidak dapat dinilai & NT \\
\hline \multicolumn{3}{|l|}{ Respons motorik/motor response (M) } \\
\hline Mematuhi dua perintah berbeda & Menuruti perintah & 6 \\
\hline Mengangkat tangan ke atas klavikula, ke arah stimulus pada kepala dan leher & Melokalisasi & 5 \\
\hline Melipat siku dengan cepat tetapi gerakan abnormal tidak dominan* & Fleksi normal & 4 \\
\hline Melipat siku, gerakan abnormal dominan* & Fleksi tidak normal & 3 \\
\hline Ekstensi siku lengan & Ekstensi & 2 \\
\hline Tidak ada gerakan lengan/tungkai (tanpa faktor penghalang) & Tidak ada & 1 \\
\hline Ada paralisis atau faktor penghambat lain & Tidak dapat dinilai & NT \\
\hline \multicolumn{3}{|l|}{ Respons verbal/verbal response (V) } \\
\hline Menyebutkan nama, tempat, dan tanggal & Orientasi baik & 5 \\
\hline Orientasi tidak baik tetapi komunikasi jelas & Bingung & 4 \\
\hline Kata-kata jelas & Kalimat & 3 \\
\hline Mengerang & Suara & 2 \\
\hline Tidak ada suara yang terdengar, tanpa faktor pengganggu & Tidak ada & 1 \\
\hline Ada faktor yang menghalangi komunikasi & Tidak dapat dinilai & NT \\
\hline
\end{tabular}

*) Lihat gambar ciri-ciri respons fleksi (Gambar 2). 
Kanan

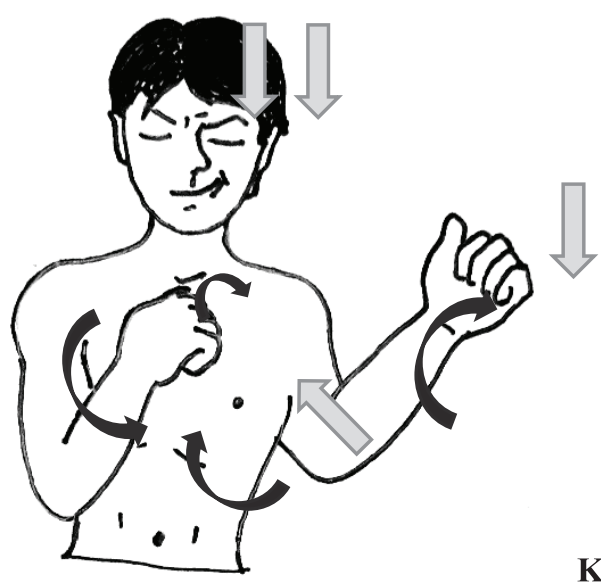

Gambar 2. Ciri-ciri Respons Fleksi

Kanan: Fleksi abnormal: Gerakan stereotip yang lambat, lengan melipat di dada, lengan bawah berotasi, ibu jari mengepal, tungkai ekstensi; Kiri: Fleksi normal: Cepat, bervariasi, lengan menjauh dari tubuh; Panah warna abu-abu adalah lokasi stimulus, panah warna hitam adalah arah gerakan.

jari tangan atau kaki atau takik supraorbita. Pemeriksa tidak dianjurkan memberikan stimulus tekan pada puting atau sternum. ${ }^{21}$

\section{Respons Motorik (Motor Response)}

Hal penting dalam menilai respons motorik adalah saat memberikan perintah. Pemeriksa diminta untuk memberikan dua perintah yang jelas dan sederhana, agar yakin pasien benar-benar memahami perintah yang diberikan, seperti: "Tolong angkat lengan kiri Bapak! Tolong pegang telinga kanan Bapak!"20-21

Selain itu, saat memberikan stimulus tekan harus menggunakan teknik yang mampu membangkitkan stimulus yang adekuat tetapi tidak mencederai pasien. Teknik yang dianjurkan adalah menekan takik supraorbita (seperti pada evaluasi komponen membuka mata) dan mencubit otot trapezius. ${ }^{21}$

Saat memberikan stimulus tersebut, amati respons pasien. Jika pasien menepis tangan pemeriksa yang sedang memberikan stimulus tekan di leher dan di kepala, maka pasien dianggap mampu melokalisasi stimulus (skor 5). Jika pasien hanya menggerakgerakkan badannya saat diberi stimulus, pasien dianggap tidak mampu melokalisasi nyeri namun melakukan fleksi normal atau menarik lengannya (withdrawing) (skor 4). Jika respons pasien berupa fleksi kedua lengan, disebut fleksi abnormal (skor 3). Istilah sikap dekortikasi dan deserebrasi tidak lagi ditulis dalam kriteria GCS yang direvisi. ${ }^{21}$

\section{Respons Verbal (Verbal Response)}

Saat memeriksa komponen respons verbal, pemeriksa juga memeriksa orientasi. Oleh karena itu, pemeriksa diminta menanyakan nama pasien, lokasi pasien berada, dan tanggal berapa. Jangan memberikan pertanyaan tertutup atau yang dapat dijawab dengan "ya" atau "tidak" saja. ${ }^{21}$

\section{Penilaian}

Saat memeriksa GCS, yang dicari adalah respons terbaik. Misalnya saat diberi stimulus tekan terlihat lengan kanan mampu melokalisasi stimulus namun lengan kiri melakukan fleksi abnormal, maka yang dipakai adalah respons lengan kanan (lebih baik). Pada beberapa keadaan seperti edema kelopak mata atau pasien dengan sedasi dan terintubasi, GCS sulit dinilai. Selain itu, GCS juga tidak sensitif terhadap fungsi batang otak (tidak ada penilaian ukuran dan reaktivitas pupil), sehingga muncul modifikasi GCS dan beberapa usulan baru untuk skala kesadaran yang lebih dapat diandalkan. Namun demikian, metode-metode tersebut masih belum diterima secara universal. ${ }^{21}$

\section{Beberapa Perubahan}

Urutan pemeriksaan GCS saat ini dianjurkan mengikuti pola seperti pada Gambar 3. Pemeriksa harus memeriksa (check) terlebih dahulu apakah ada faktor-faktor yang mengganggu kemampuan pasien untuk memberikan respons terbaik, seperti edema berat di kelopak mata, dalam sedasi atau 
terintubasi, dan ada kelumpuhan anggota. Setelah itu pemeriksa mengamati (observe) pasien, memberikan stimulus (stimulate) yang sesuai jika diperlukan, dan memberikan nilai (score). ${ }^{21}$

Istilah stimulus "nyeri" saat ini tidak dipakai lagi, diganti dengan stimulus "tekan". Alasannya adalah karena persepsi nyeri bersifat subjektif. Pemeriksa memberikan stimulus tetapi persepsi nyeri akan berbeda-beda menurut pasien (dalam hal evaluasi GCS, dipengaruhi oleh tingkat kesadaran pasien). Selain itu, perubahan ini sesuai dengan tren rumah sakit yang berusaha meminimalkan keluhan nyeri pada pasien. ${ }^{21}$

Istilah "menuruti perintah" pada respons motorik saat ini diartikan sebagai "mematuhi dua perintah berbeda". Istilah "melokalisasi nyeri" diubah menjadi "melokalisasi" dan diartikan sebagai "mengangkat tangan ke atas klavikula, ke arah stimulus pada kepala dan leher". Istilah kriteria terbaru. Keterangannya ditulis di luar skala. ${ }^{21}$

Seperti yang telah dijelaskan sebelumnya, lokasi pemberian stimulus tekan juga mengalami perubahan. Lokasinya saat ini adalah di bantalan kuku jari tangan atau kaki, takik supraorbita, dan otot trapezius, tidak diberikan di sternum atau puting. ${ }^{21}$

Perbandingan dengan Skala Penilaian Kesadaran Lain

Glasgow Coma Scale bukan satu-satunya skala penilaian kesadaran. Ada banyak skala lain yang pernah atau masih dipakai di seluruh dunia, antara lain Ommaya Vital Chart, Alert-Verbal Response-Pain Response-Unresponse (AVPU), Innsbruck Coma Scale (ICS), Glasgow-Liege Scale (GLS), Pittsburgh Brain Stem Score (PBSS), Adelaide Pediatric Coma Scale, Blantyre Coma Scale, Edinburgh-2 Coma Scale (E2CS), Reaction Level Scale (RLS85), Full Outline of UnResponsiveness (FOUR), dan yang

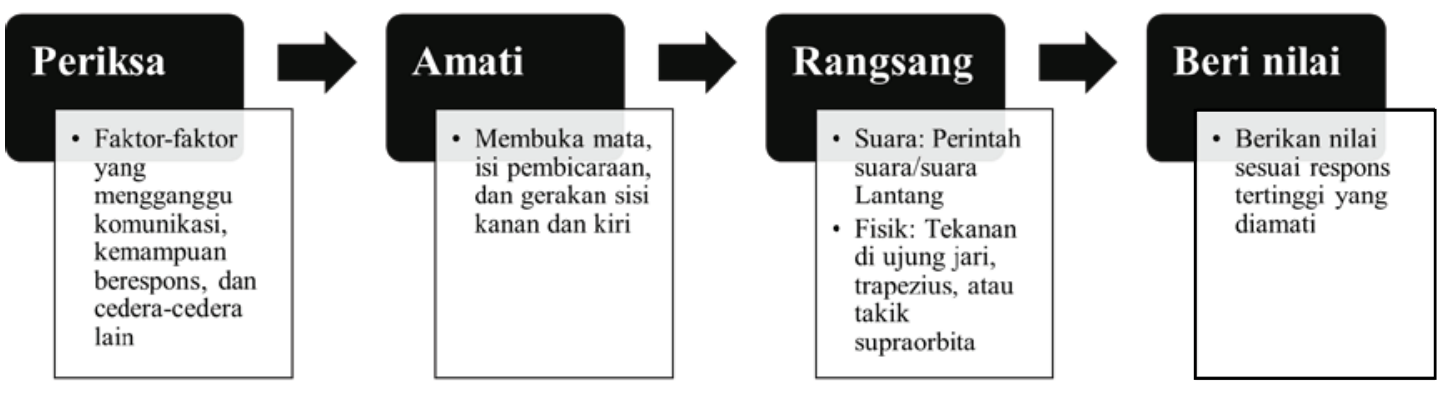

Gambar 3. Urutan Pemeriksaan GCS ${ }^{19}$

"menghindari nyeri" diganti menjadi "fleksi normal" dan didefinisikan sebagai "melipat siku dengan cepat tetapi gerakan abnormal tidak dominan". Istilah "fleksi abnormal/dekortikasi" diganti menjadi "fleksi abnormal" dan didefinisikan sebagai "melipat siku, gerakan abnormal dominan". Istilah "ekstensi/ deserebrasi" diganti menjadi "ekstensi". Hal ini ditujukan untuk memperjelas interpretasi penilaian respons motorik yang memang sering kali berbeda antar pemeriksa. ${ }^{20}$

Dianjurkan juga untuk menyeragamkan istilah keterbatasan pemeriksaan seperti " $x$ " (tidak dapat diperiksa), "edema" (edema palpebra), "sedasi", "ett" (terpasang pipa endotrakea), dan "afasia motorik", menjadi NT (not testable) seperti tertulis dalam paling komprehensif, Comprehensive Level of Consciousness Scale (CLOCS). Pemakaiannya ada yang hanya digunakan pada populasi khusus ataupun populasi umum dengan alasan dan tujuan penggunaan yang berbeda-beda. ${ }^{1,14,22}$

Pada tahun 1981, Innsbruck University Hospital mengembangkan skala penilaian koma yang disebut ICS. Skala ini menilai delapan komponen, yaitu membuka mata, reaksi terhadap rangsangan akustik, reaksi terhadap nyeri, postur tubuh, ukuran pupil, reaksi pupil terhadap cahaya, posisi dan gerakan bola mata, serta otomatisme oral. Skala ini terutama ditujukan untuk memprediksi luaran pasien trauma dengan penurunan kesadaran. Penelitian Benzer dkk memperlihatkan bahwa ICS memiliki akurasi prediksi yang tinggi untuk luaran buruk 
pada pasien dengan skor ICS yang rendah. Namun demikian, skala ini tidak banyak digunakan di luar negara tempatnya dibuat. ${ }^{1}$

Glasgow-Liege Scale merupakan skala yang dikembangkan pada tahun 1982 di Liege, Belgia oleh Born dkk. Skala ini dibuat untuk mengakomodasi refleks-refleks batang otak dalam penilaian kesadaran, yaitu refleks frontoorbikular, okulosefalik vertikal, pupil, okulosefalik horizontal, dan okulokardiak. Kelima refleks batang otak ini akan menghilang atau menghilang secara bertahap jika terjadi herniasi rostrokaudal. ${ }^{1}$

Glasgow Coma Scale juga dimodifikasi untuk pasien anak, terutama pada aspek komunikasi dan pembuatan kelompok usia. Salah satu skala GCS pediatrik yang dipakai adalah Skala Koma Pediatrik Adelaide (Adelaide Pediatric Coma Scale) atau disebut juga Pediatric Glasgow Coma Scale (PGCS). Pada skala ini, komponen respons motorik hanya memiliki nilai tertinggi 5 , sehingga rentang skor totalnya menjadi 3-14. Skor total normal juga dimodifikasi menurut usia menjadi: 9 (usia 0-6 bulan), 11 (usia 6-12 bulan), 12 (usia 1-2 tahun), 13 (usia 2-5 tahun), dan 14 (usia $>5$ tahun). ${ }^{1}$

Skala lain yang dimodifikasi dari GCS adalah Skala Koma Blantyre (Blantyre Coma Scale) yang dibuat oleh Taylor dan Molyneux tahun 1987 untuk mengevaluasi malaria serebral pada anak dalam penelitian di kota Blantyre, Malawi. ${ }^{1}$

Seperti yang telah disebutkan sebelumnya, GCS memiliki beberapa keterbatasan, terutama untuk mengevaluasi fungsi batang otak. Oleh karena itu, salah satu alternatif penggantinya adalah skor Full Outline of UnResponsiveness (FOUR) untuk penilaian koma yang lebih baik. ${ }^{14}$ Skor ini dikembangkan oleh Wijdicks dkk dari Departemen Neurologi Mayo Clinic, Rochester, Minnesota, Amerika Serikat pada tahun 1998 yang dipublikasikan pada tahun 2005 . Skor ini telah divalidasi juga di beberapa negara termasuk Cina. ${ }^{23}$

Full Outline of UnResponsiveness mengevaluasi respons mata, respons motorik, refleks batang otak, dan pola respirasi (Tabel 2) dengan menggunakan skor antara 0-4 untuk tiap komponen.
Inter-observer reliability skor ini juga sedikit lebih baik daripada GCS. Namun demikian, skor ini belum diadaptasi secara luas di Indonesia, sehingga dapat menyulitkan komunikasi antar fasilitas kesehatan, termasuk dalam sistem rujukan berjenjang. ${ }^{14}$

Tabel 2. Full Outline of UnResponsiveness Score ${ }^{14}$

\section{Respons mata}

4: Kelopak mata terbuka atau pernah terbuka dan mengikuti arah atau berkedip oleh perintah.

3: Kelopak mata terbuka namun tidak mengikuti arah.

2: Kelopak mata tertutup namun terbuka jika mendengar suara keras.

1: Kelopak mata tertutup namun terbuka oleh rangsang nyeri.

0: Jika kelopak tetap tertutup dengan rangsang nyeri.

\section{Respons motorik}

4: Ibu jari terangkat, atau mengepal, atau tanda "damai" (peace sign).

3: Melokalisasi nyeri.

2: Memberi respons fleksi pada rangsang nyeri.

1: Respons ekstensi.

0 : Tidak ada respons terhadap nyeri atau status mioklonus umum.

\section{Refleks batang otak}

4: Terdapat refleks pupil dan kornea.

3: Salah satu pupil melebar terus menerus.

2: Tidak ada refleks pupil atau kornea.

1: Tidak ada refleks pupil dan kornea.

0 : Tidak ada refleks pupil, kornea, atau batuk.

\section{Respirasi}

4: Pola napas regular, tidak terintubasi.

3: Pola cheyne-stokes, tidak terintubasi.

2: Pola napas iregular, tidak terintubasi.

1: Napas dengan kecepatan di atas ventilator, diintubasi.

0: Apneu atau pernapasan dengan kecepatan ventilator.

\section{Relevansi GCS di Masa Kini}

Setelah lebih dari 40 tahun, banyak kemajuan dalam evaluasi kesadaran beserta alat bantu untuk menilai kelainan otak. Selain itu, sudah dikembangkan beberapa skala penilaian kesadaran lain seperti skor FOUR. Glasgow Coma Scale sendiri memerlukan pemeriksaan tambahan untuk memastikan gangguan fokal otak. Jadi, apakah GCS masih relevan digunakan?

Secara statistik, tidak ada metode penilaian kesadaran yang dapat mengalahkan GCS dari segi popularitas. Artikel Teasdale dan Jennett di Lancet tahun 1974 tentang GCS merupakan salah satu manuskrip klasik yang paling banyak dikutip pada tahun 2010. Data dari Web of Science memperlihatkan 
manuskrip tersebut dikutip sekitar 300 kali pertahun antara tahun 2010-2012 (McAinsh, 2014). Suatu angka yang besar untuk sebuah manuskrip. Glasgow Coma Scale juga telah digunakan di lebih dari 80 negara dan telah diterjemahkan ke bahasa nasional di $74 \%$ dari negara-negara tersebut. Sebagian besar penelitian tentang gangguan neurologis, terutama cedera kepala, menggunakan GCS untuk mencatat tingkat kesadaran. ${ }^{4,-10}$

Keunggulan GCS terletak pada nilai kesederhanaannya yang masih relevan sampai saat ini. Dengan cara pemeriksaan yang sederhana, seseorang mampu memperoleh informasi terkait keputusan terapi dan prognosis pasien., ${ }^{6,24}$ Untuk prognosis cedera kepala, terdapat faktor-faktor yang berperan, seperti usia, reaktivitas pupil, gambaran pencitraan otak, kadar hemoglobin, kadar leukosit, kadar glukosa darah, profil limfosit, beberapa penanda proteomik atau digabungkan lewat model matematis. ${ }^{725-33}$ Namun tidak semuanya memperlihatkan hubungan yang kuat ataupun dapat diperiksa secara praktis seperti GCS.

Khusus di unit perawatan intensif, FOUR lebih mungkin menjadi tempat penerapan karena memiliki komponen evaluasi sebagian fungsi batang otak dan respirasi yang terintegrasi dalam satu metode. ${ }^{14} \mathrm{Pada}$ akhirnya, nilai prognostik GCS memang sudah tidak relevan jika hanya digunakan secara sendiri, perlu diperhitungkan faktor prognosis lain seperti pupil, usia, hasil pencitraan otak, dan sebagainya.

\section{Pengembangan di Masa Depan}

Brennan dkk membuat suatu kombinasi matematik antara skor GCS dan respons pupil. ${ }^{34-35}$ Evaluasi pupil dianggap merupakan petunjuk penting fungsi batang otak dan tidak sulit dikerjakan. Dengan demikian, pemeriksaan ini tetap memiliki nilai kesederhanaan. Hasil kombinasi ini dibandingkan dengan beberapa metode lain yang lebih rumit untuk menilai kerusakan otak. Metode penilaian GCS yang digunakan masih sama, tetapi dikembangkan suatu skor penilaian respons pupil terhadap cahaya yang disebut skor reaktivitas pupil (pupil reactivity score/ PRS). ${ }^{34}$

Pupil reactivity score ditentukan sebagai berikut: skor 2 jika kedua pupil tidak reaktif terhadap cahaya; skor 1 jika hanya satu pupil yang tidak reaktif terhadap cahaya; dan skor 0 jika semua pupil yang reaktif terhadap cahaya. Selanjutnya dibuat skor kombinasi yaitu Glasgow Coma Scale-Pupil Score (GCS-P) dengan mencari selisih antara GCS dan PRS. Nilai GCS-P berada antara angka 1-15 karena skor GCS berada pada rentang 3-15 dan PRS 0-2. Dari penelitian ini disimpulkan bahwa GCS-P mampu memberikan informasi tentang luaran pasien yang setara dengan metode penilaian lain yang lebih kompleks. Selain itu, GCS-P mampu memberikan informasi tambahan tentang prognosis pada pasien dengan skor GCS yang rendah. ${ }^{34}$

Usia dan hasil CT scan kepala juga merupakan faktor penentu prognosis yang penting. Murray dkk menganggap bahwa usia (age) dapat dikombinasikan dengan GCS-P secara matematis untuk memperkirakan prognosis cedera kepala. ${ }^{34}$ Informasi tentang usia/perkiraan usia hampir selalu ditemukan dalam data pasien, sehingga tidak menambah beban pemeriksaan. Metode disebut metode GCS-P plus age (GCS-PA) yang memberikan informasi nilai prognosis pasien cedera kepala yang lebih baik dibanding penilaian yang dilakukan sendirisendiri. ${ }^{27-28}$

Selanjutnya, dikombinasikan empat faktor penentu prognosis menggunakan model matematis, dinamakan GCS-P plus age plus CT findings (GCSPA CT).${ }^{27}$ Namun harus diakui bahwa CT scan kepala tidak selalu dapat segera dikerjakan pada pasien cedera kepala, apalagi pada area yang masih terbatas fasilitas seperti di negara kita.

\section{KESIMPULAN}

Metode GCS masih merupakan metode evaluasi kesadaran secara kuantitatif yang mudah dikerjakan, pada kasus trauma dan nontrauma. Evaluasi ini bermanfaat dalam pengambilan keputusan klinis pada pasien, komunikasi antar petugas, dan menentukan prognosis. Terdapat beberapa perubahan pada penilaian GCS untuk meningkatkan standarisasi dan memperbaiki inter-observer reliabilility. Namun GCS juga memiliki keterbatasan, sehingga perlu dikombinasikan dengan faktor penentu prognosis lain. 


\section{DAFTAR PUSTAKA}

1. Wijdicks EF. Clinical scales for comatose patients: the Glasgow Coma Scale in historical context and the new FOUR Score. Rev Neurol Dis. 2006;3(3):10917.

2. Gill M, Windemuth R, Steele R, Green SM. A comparison of the Glasgow Coma Scale score to simplified alternative scores for the prediction of traumatic brain injury outcomes. Ann Emerg Med. 2005;45(1):37-42.

3. Manley, Geoffrey T, Maas AR. Traumatic brain injury an international knowledge-based approach. J Am Med Assoc. 2013;94110:9-10.

4. Teasdale G, Maas A, Lecky F, Manley G, Stocchetti N, Murray G. The Glasgow Coma Scale at 40 years: standing the test of time. Lancet Neurol. 2014;13(8):844-54.

5. Teasdale G, Jennett B. Assessment of coma and impaired. Lancet. 1974;2:81-4.

6. Teasdale G, Jennett B, Murray L, Murray G. Glasgow coma scale: to sum or not to sum. Lancet. 1983;2:678.

7. Tangkudung G, Sampurna JMP, Khosama H. Hubungan jumlah leukosit dengan gangguan fungsi eksekutif pada cedera kepala ringan-sedang. Neurona. 2016;33(3):e1-7.

8. Roozenbeek B, Maas AIR, Menon DK. Changing patterns in the epidemiology of traumatic brain injury. Nat Rev Neurol. 2013;9(4):231-6.

9. Reith FCM, Lingsma HF, Gabbe BJ, Lecky FE, Roberts I, Maas AIR. Differential effects of the Glasgow Coma Scale Score and its components: an analysis of 54,069 patients with traumatic brain injury. Injury. 2017;48(9):1932-43.

10. Maas AI, Menon DK, Steyerberg EW, Citerio G, Lecky F, Manley GT, dkk. Collaborative European neurotrauma effectiveness research in traumatic brain injury (CENTER-TBI): a prospective longitudinal observational study. Neurosurgery. 2015;76(1):67-80.

11. American College of Surgeon. Advanced Trauma Life Support (ATLS $\left.{ }^{\circledR}\right)$. Edisi ke-10. Chicago: American College of Surgeons; 2018. h. 102-27.

12. Carney N, Totten AM, O'Reilly C, dkk. Guidelines for the management of severe traumatic brain injury. Edisi ke-4. Neurosurgery. 2017;80(1):6-15.

13. Rutledge R, Lentz C, Fakhry S, Hunt J, Rutledge R, Lentz CW. Appropriate use of the Glasgow Coma Scale in intubated patients: a linear regression prediction of the Glasgow verbal score from the Glasgow eye and motor scores. J Trauma. 1996;41:514-22.

14. Wijdicks E, Bamlet W, Maramattom B, Al E. Validation of a new coma scale: the FOUR score. Ann Neurol. 2005;58:585-93.
15. Hutchinson PJ, Kolias AG, Timofeev IS, dkk. Trial of decompressive craniectomy for traumatic intracranial hypertension. N Engl J Med. 2016;375(12):1119-30.

16. Riechers R, A R, Brown W, Physician dkk. Physician knowledge of the Glasgow Coma Scale. J Neurotrauma. 2005;22:1327-34.

17. Reith FCM, Van den Brande R, Synnot A, Gruen R, Maas AIR. The reliability of the Glasgow Coma Scale: a systematic review. Intensive Care Med. 2016;42(1):3-15.

18. Osler T, Cook A, Glance LG, dkk. The differential mortality of Glasgow Coma Score in patients with and without head injury. Injury. 2016;47(9):1879-85.

19. Teasdale G, Allan D, Brennan P, McElhinney E, Mckinnon L. Forty years on: updating the Glasgow Coma Scale. Nurs Times. 2014;110(42):12-6.

20. Teasdale G. The Glasgow structured approach to assesment of the Glasgow Coma Scale. Glasgowcomascale [serial online]. 2014 [diakses 12 September 2018]. Tersedia dari: Royal Collage of Physicians and Surgeons of Glasgow.

21. Kembuan MAHN, Mahama CN. Kesadaran \& fungsi luhur. Dalam: Mawuntu AHP, Kembuan MAHN, Tanawal BJ, editor. Pemeriksaan neurologi dasar: suatu pendekatan terstuktur. Manado: Bagian Neurologi FK Unsrat; 2018. h. 44-53.

22. Rosenbaum AM, Giacino JT. Clinical management of the minimally conscious state. Edisi ke- 1 . Handb Clin Neurol. 2015;127:395-410.

23. Peng J, Deng Y, Chen F, dkk. Validation of the Chinese version of the FOUR score in the assessment of neurosurgical patients with different level of consciousness. BMC Neurol. 2015;15(1):1-8.

24. Yuliani D, Adnyana IMO, Purwata TE, Widyadharma E. Skala koma Glasgow awal sebagai prediktor nyeri kepala kronik pascatrauma kepala nonbedah. Neurona. 2013;30(2):e1-e8.

25. Dharmajaya R. Kadar Protein S100B serum 120 jam pertama sebagai faktor prognostik pada cedera kepala berat. Neurona. 2014;31(4):e1-8.

26. Silverberg N, Garner A, Brubacher J, Panenka W, Li J, Iverson G. Systematic review of multivariable prognostic models for mild traumatic brain injury. J Neurotrauma. 2015;15(32):517-26.

27. Raj R, Siironen J, Skrifvars MB, Hernesniemi J, Kivisaari R. Predicting outcome in traumatic brain injury: development of a novel computerized tomography classification system (Helsinki Computerized Tomography Score). Neurosurgery. 2014;75(6):632-46.

28. Thelin EP, Nelson DW, Vehvilainen J, Nystrom H, Kivisaari R, Siironen J, dkk. Evaluation of novel computerized tomography scoring systems in human 
traumatic brain injury: an observational, multicenter study. PLoS Med. 2017;14(8):1-19.

29. Moore NA, Brennan PM, Baillie JK. Wide variation and systematic bias in expert clinicians' perceptions of prognosis following brain injury. Br J Neurosurg. 2013;27(3):340-3.

30. Okonkwo DO, Yue JK, Puccio AM, dkk. GFAPBDP as an acute diagnostic marker in traumatic brain injury: Results from the prospective transforming research and clinical knowledge in traumatic brain injury study. J Neurotrauma. 2013;30(17):1490-7.

31. Babcock L, Byczkowski T, Wade SL, Ho M, Mookerjee S, Bazarian JJ. Predicting postconcussion syndrome after mild traumatic injury in children and adolescents who present to the emergency department. JAMA Pediatr. 2013;167(2):156-61.

32. Yuh E, Mukherjee P, Lingsma HF, Yue JK, Ferguson
AR, Gordon WA. MRI improves 3-month outcome prediction in mild traumatic brain injury. Ann Neurol. 2013;72(2):224-35.

33. Giza CC, Kutcher JS, Ashwal S, Barth J, Getchius TS, Gioia GA, dkk. Summary of evidence-based guideline update: evaluation and management of concussion in sports: report of the Guideline Development Subcommittee of the American Academy of Neurology. Neurology. 2013;80(24):2250-7.

34. Murray GD, Brennan PM, Teasdale GM. Simplifying the use of prognostic information in traumatic brain injury. Part 1: the GCS-Pupils score: an extended index of clinical severity. Ann Surg. 2018;128(6):188-94.

35. Steyerberg EW, Moons KG, van der Windt DA, Hayden JA, Perel P, Schroter S, dkk. Prognosis research strategy (PROGRESS) series 3: prognostic model research. PLoS Med. 2013;10(2):e1001381. 